\title{
Short Run Economic Impact of Disruptive Technologies in Emerging Economies
}

\author{
S. Sadare \\ Founder \& Director, IdeaNutz, Mumbai \\ \{sachin_sadare@yahoo.com\}
}

\begin{abstract}
The wave of digital technologies is spreading in emerging economies like India. Concepts like Smart Cities and Digital India are becoming popular buzzwords across the population. Through this euphoria of a new digital future, it is now recognized that such a change will be enabled by adopting the new digital technologies like Mobility, Cloud, Big Data, Analytics, Robotics and Internet of things, among others. Whenever new technological advances are adopted, the future after a couple of decades looks well settled but there is always short run economic fallout (impact) of such technology disruptions. The key is to recognize the short run economics and be prepared with the right tools to tackle it. It is even more important for emerging economies to understand the short run economic fallouts as the consequences can otherwise be catastrophic. This paper highlights some of the short run economic fallouts due to digital technology disruption especially in emerging economies, using India as an example to substantiate the points expressed. It also suggests economic policies that can help tide the short run fallouts of such technology disruptions .
\end{abstract}

Keywords : Economics; Macroeconomics; developing economies; Internet of Things; Big Data and Analytics; Digital Transformations; short run economics

\section{Introduction to Disruptive Technologies}

The world is today at the cusp of a major technology disruption - digital transformation. There are multiple facets of digital transformation which makes it a well-oiled inter-related web of various technologies. The key elements of a digital transformation are the SMAC (Social, Mobile, Analytics and Cloud) technologies that are today considered as a must for any organization across the globe. Social is about using social media networks for reaching out to the end consumers and understanding their demand pulse . Mobile is about the last mile connectivity with all the stakeholders - customers, partners and employees. Analytics is about deriving insights from the organizational data and pivoting business strategies to align with the insights. Cloud is about converting the business model from predominantly a CAPEX model into a pay-as-you-go OPEX model . CIOs have invested in each of the four technologies in different permutations and combinations to ensure they have a digital strategy in place.

But what really drives the technology disruptions are the digital technologies that are built using SMAC as the foundational layer. These include Internet of Things, Robotics, Automation, Machine Learning, 3D printing, User Experience, Big Data, Wearable, Augmented Reality, Virtual Reality and many more. Each of these works with the SMAC layers and with each other to create a huge digital transformation, which is now being considered as an inevitable technology disruption. Technology disruption today is not only impacting the IT strategy but also the corporate business strategy. Hence not only the CIOs or the CTOs are watching it carefully, but even the CEOs, COOs, CMOs, CSOs, HR teams and employees are watching with great interest. Even the governments need to keep note of this forthcoming disruption to ensure that it has the right policies in place to manage the macroeconomic indicators .

\section{Impact of Technology Disruption on Macroeconomic Indicators}

The Circular Flow Model (Mankiw) is a visual model of an economy and shows how money flows in a circular manner between the households, firms and the government.

B. Iyer, S. Nalbalwar and R. Pawade (Eds.)

ICCASP/ICMMD-2016.Advances in Intelligent Systems Research.

Vol.137, Pp.793-797.

(C) 2017- The authors. Published by Atlantis Press

This is an open access article under the CC BY-NC license (http://creativecommons.org/licens)es/by-nc/4). 


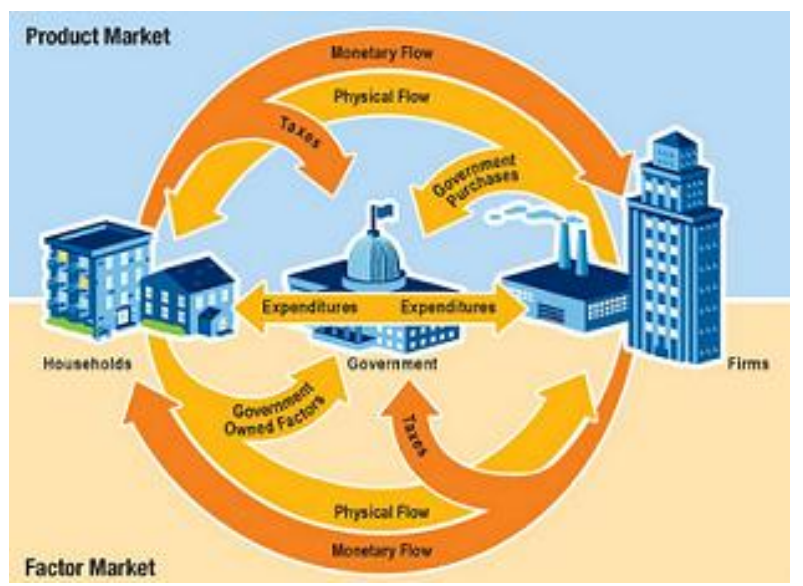

Fig. 1. Circular Flow Model, Adapted from Mankiw (2014)

If any link is disturbed, it can impact the flow of money in the economy. The circular flow model is the key to understanding the short run impact of technology disruption in emerging economies .

There are four points of essential importance to understand about the circular flow diagram .

(1) Households and firms interact in the market for products, services and factors of production. These mar-

kets are controlled by the governments either directly or through regulations .

(2) For products and services, households are the buyers and firms the sellers.

(3) For factors of production, firms are the buyers and households the sellers .

(4) A government collects taxes from both - households and firms- and spends to provide public goods that make the market a more efficient place for households and firms to interact .

Technology is one of the important factors of production for the firm. Firms use technology advancements to better their business functions and become more profitable. The demand for technology as a factor of production is high because it creates products and services that are valued by the end consumer. It creates a selfsustaining cycle where more technology advancements mean better profitability for the firm .

Digital transformation is one such disruptive technology that is creating a self-sustaining cycle of technology advancements. Every digital technology enabler is having a symbiotic relationship with the others. There is an overall positive impact of such a symbiosis on the operability of the firm.

For an emerging economy, all the three stakeholders - governments, firms and households - need to watch out for the technology disruption heading their way and be better prepared to face the onslaught. Let us analyze how disruptive technology as a factor of production affects the key macroeconomic indicators of an emerging economy like India in the short run .

\section{$2.1 \quad G D P$}

Emerging economies do not have access to the new technologies for a few years or even decades. It is mainly a prerogative of the developed western countries that make R\&D investments to further technology advancements. Imports of such technology increases as firms in emerging economies are anxious to purchase them at high costs from the developed countries. As cost of technology as factor of production increases, in the short run, it results in lower profitability than before, creating cost pressures on the firms operating in the emerging economies. Hence real GDP growth in the short run, in such economies, is negative. Thus, in the short run, real growth in emerging economies has a negative correlation with the technology advancements made in the western world.

Ironically, even though India has been an emerging economy over the last few decades, it has a good global standing as a key exporter of software based services. However this does not insulate it from the negative correlation between real GDP growth and technology advancements .

\subsection{Unemployment}

Firms in an emerging economy will always adopt new technology to produce competitive and quality products / services in the globalized world. However, in the short run, the adoption results in lower profitability putting cost reduction pressures on the firm. Firms inadvertently resort to retrenching people for two reasons : 
technology adoption has made some jobs redundant and (2) reducing workforce allows the firm to operate at a higher efficiency. Thus in emerging economies, in the short run, adoption of new age technologies results in increased unemployment. Especially with digital transformation, there is going to be massive surge of unemployed population in emerging economies .

India will also see a lot of jobs becoming redundant as the pressure to reduce costs by firms increase . Business and operating models will see a paradigm shift, a movement away from people based services to digital technology enabled services .

\subsection{Inflation}

As the cost of technology as a factor of production increases, in the short run, firms will have no choice but to increase the selling price of the products / services to maintain profitability. As more and more firms exhibit such a behavior, it results in inflationary pressures and a steady rise in prices of everyday goods and services . If emerging economies do not handle the impact of technology disruption, it results in high inflation rates in the short run, primarily due to increased costs of all goods and services .

India is just starting to see moderate inflation rates. However if the firms operating in the Indian economy do not invest in technology research and development ( R\&D), India may also face high inflation rates in the short term.

\section{$2.4 \quad$ Foreign Exchange Rates}

Emerging countries end up importing technology solutions from the developed countries. Not all companies can afford to adopt the latest technologies right from the initial stages. It results in a lack of competitiveness in the hugely globalized world. Exports start to dwindle. The demand for local currency in global market diminishes starting a trend for the depreciation of the currency in the global market. Thus in the short run, emerging economies will have to deal with devalued currency with the advent of highly disruptive technology as a factor of production.

Indian software exports will be hugely hit if Automation succeeds in making millions of engineering jobs redundant. It will lead to a devalued Indian currency in the global market .

Thus if not mitigated through proper planning and execution, technology disruption can have a negative impact on GDP growth, inflation, employment and value of currency in the global market. Technology disruption can have a huge short run negative impact on the key macroeconomic indicators of an emerging economy .

\section{Factors of Short Run Impact in Emerging Economies}

Let us also analyze why emerging economies are vulnerable to such negative impact of technology disruption . Here it is important to understand that we are primarily looking at the short run impact of technology disruption. How emerging economies navigate through the short term, determines how strong or weak they emerge in the long run .

\subsection{Increase in Unemployment}

In an emerging economy, technology disruption results in negative real growth and high inflation . Technology can also result in massive job redundancy thereby eliminating a huge section of the working population from the job market.

In India, in the 1960s, when industrial revolution took place, huge machinery replaced the mill workers . Most of the mill workers of the 1960s never worked again. They were not reskilled enough to take up another job. A lot of families had to go through prolonged sustained poverty due to industrialization .

Again in the 1990s, a whole generation of B.Com. (Bachelor of Commerce) students went jobless because accounting and finance could now be done with computers - easily, accurately and cost efficiently. Those who did not retrain found themselves out of the job market. India will face a similar situation around 2020 when a huge number of engineers (fresh and experienced) will suddenly realize they do not have the necessary skills to work in the digital technology environment. A lot of legacy jobs in the software engineering field will be at stake.

Automation is going to make low cost software development based business model of IT firms irrelevant . Middle level and senior level employees of the IT industry will find themselves in a problem if they do not quickly adapt to the needs of a new technology driven digital world. IT firms will revisit their business and operating models and effect changes to remain profitable. A huge impact can be expected in the multi-billion 
IT enabled software services industry. This can have a spiraling impact on the major cities and towns like Bangalore, Pune, Hyderabad and Coimbatore where IT also drives the ancillary industries and professions. If not managed properly, this can quickly spiral in an era of high unemployment .

\subsection{Socialist Economy}

Most emerging economies are under a socialist rule. The wellbeing of the working class is considered as paramount in a socialist economy. Business decisions that are against the worker benefits are avoided or not allowed by the government and their agencies. Hence the short run impact of the technology disruption drags longer than it would otherwise in a capitalist economy. Delayed decisions in socialist economies do not in any way help to mitigate the negative impact of the technology disruption. A socialist environment only prolongs the effect of the short run impact on the economy. A socialist thinking in adverse times only makes things worse in the long run .

In India, during the mill workers displacement (1960s), unions and strikes made it difficult for firms to move on with the industrialization. The workers faced a hard ordeal each day, where they were neither reskilled for other jobs nor did the promised mill jobs materialized. A generation of mill workers and their families were lost to unemployment and poverty.

In the 1990s, India had opened up its economy . Commerce students did not get jobs but due to an open economy, they could try different businesses or trade in stock markets to earn a livelihood. A bunch of entrepreneurs developed. Slowly the IT sector and the BPO sector opened up and commerce students took appropriate jobs in these sectors. Banks offered their employees voluntary retirements and passed on their jobs to the computers. The impact in the $1990 \mathrm{~s}$ was not as severe as in the 1960s. It was mainly due to the government initiatives to move away from socialist mindset .

It is imperative that in the near future, the government looks at tackling the technology disruption head-on with a more capitalist approach. A socialist approach only helps in prolonging the misery and the unhappiness of the workers impacted.

\subsection{Weak Institutions}

Any thoughtful plan needs to be implemented well to showcase the expected results. However most emerging economies are mired with political instabilities and weak national institutions. Corruption becomes the center stage for approving or implementing any economic plan. Thus when the vices as above exist in an economy, it is almost impossible for the economy to rise against the challenges faced. When an economy is fighting technology disruption, weak political class and institutions make the matters worse .

India has seen coalition government for almost 20 years before the 2014 elections. The central bank (RBI), SEBI and others are independent institutions that work for the betterment of the overall population. Hopefully in 2016, India can expect a stronger political will from a stable government that will look forward to removing the inefficiencies that exist in the weaker national institutions and to implement the plans that bring about the desired results .

Thus some of the factors to take care of in the short run, during times of high technology disruption are - high unemployment, socialist inclinations and weak national institutions. Any plan to combat the short run economic impact of technology disruption should address the above three factors satisfactorily .

\section{Mitigating the Short Run Economic Impact of Technology Disruption}

India is at the cusp of technology disruption along with the rest of the global economy. It is imperative that there is foresight to deal with such a situation and the right political and business decisions are taken. To emerge stronger against the backdrop of technology disruption, India will have to make and implement economic decisions quickly.

\subsection{Training, Education, Skilling and Reskilling}

Indian government has already initiated the ideas of digital India and smart cities. Cities and infrastructure to be converted into smart assets have been identified. Budgets have been allocated. These are all steps in the right direction by the government .

Now the government needs to ensure that there are enough programs or incentives for firms to reskill the working population of India rather than importing high technology solutions from abroad. High unemployment can 
be mitigated if the funds allocated to the digital India and smart city initiatives are properly utilized to reskill and generate employment across all levels in the Indian economy .

Private firms have to be engaged in a PPP mode to incentivize them to invest in the R\&D of new technologies that will create jobs at all levels domestically. Educational institutes need to be incentivized to include curriculum that will allow students to be industry ready right after their education. Households need to inculcate new learning habits in their children and support them in becoming the workforce for the digital global world of tomorrow. The right involvement of government and firms, supported by the households can help lower the unemployment figures in India arising out of technology disruption .

\subsection{Labour Reforms}

Labour laws that are not aligned with the needs of the technologically disrupted economy are only going to prolong the sufferings of the workers (households), ultimately impacting the profitability and the operability of the firms. Taxes collected by the government are going to dwindle in the face of unemployment and recession.

Government has to give away the socialist approach of protecting worker jobs from the hands of the firms. Instead, government should quickly initiate labour reforms that align with the needs of the new economy based on technology disruption. Reforms that meet not only the needs of the firms but also allow households to quickly participate in the job market with renewed skills are the order of the day. Any delay in labour reforms will only delay the inevitable and effectively prevent a huge number of unemployed workforce to get back into the job market earlier when they are still capable of being retrained and reskilled.

\subsection{Privatization, Deregulation and Opening up of Markets}

Weak institutions promote corruption and kill the purpose for which innovative plans need to be implemented at quick speed. The most effective way to mitigate weak institutions and corrupt bodies is to deregulate the industries that are covered by these institutions and bodies. Lesser the power that the institutions hold, the lesser impact they will have on implementation of plans. Privatization of state owned assets and opening up of the local economy will also make the economy a competitive environment. A perfect competitive environment drives away the inefficiencies of the markets and thus the economy.

Thus the three challenges of high unemployment, socialist inclinations and weak institutions can be mitigated through reskilling initiatives, labour reforms and opening up of the economy through deregulation and privatization. In the short run, technology disruption can have a huge negative impact on an emerging economy like India but with the right approach, smart initiatives and strong political will, it can be met head-on and converted into an asset for the nation.

\section{Conclusion}

Technology disruption, especially the one like digital transformation, always has a negative short run impact on the macroeconomic indicators of an emerging economy. It is important that the impact is understood by all the three stakeholders of the economy - firms, governments and households. Appropriate steps are expected from all the three stakeholders in the short run, to ensure that the onslaught of technology disruption is met head-on and turned into an advantage. By doing so, technology disruption can be converted into a selfsustained high economic growth lever for an emerging economy like India .

\section{References}

[1] N. Gregory Mankiw, Principles of Economics, Thomson, 7th Edition, 2014 . 